\title{
An Examination of Economic Risks' Perception of Thai Real Estate Developers
}

\author{
Sukulpat Khumpaisal
}

\begin{abstract}
Economic risk plays a critical role in real estate development projects as it directly affects project's income stream. This paper examines Thai real estate practitioners' perception of economic risks caused by several related factors such as financial or marketing aspects. The quantitative research approach is adopted and the Explorative factor analysis (EFA) has been carried out. It is based on a survey of Thai real estate practitioners, which was conducted in mid-2010 with a response rate of $52.5 \%$ (210 out of 400$)$. This paper clusters the degree of economic risks into the appropriate categories by using the EFA technique. It finds that Thai practitioners emphasize on the economic risks caused by variation of construction materials' price more than the others Moreover, this paper underpinned that the economic risks in this industry are mostly involved with macroeconomic, financial/monetary, and marketing factors. Finally, this paper contributes the economic risk assessment model, which was established based on the solid statistical/mathematical framework that appropriate for the real estate industry.
\end{abstract}

Index Terms-Economic risks, explorative factor analysis (EFA), risk assessment, Thailand real estate development industry.

\section{INTRODUCTION}

Uncertainties in economic and financial situation cause strong impact to the real estate development process, since the project sponsors normally required the highest return of investment, and they have to bear the high economic and financial risk as well. The typical economic risks in real estate projects are caused by the variation of interest rate, loan and developer credit, sources of development funds and project debt/equity ratio [1]-[4]. Normally, project sponsors require the highest life cycle value of the properties, which could be measured by Net present value (NPV) achieved from the investment [5], [6]. Risks associated with economic and financial uncertainties could strongly affect the project development process and that was the reason that the real estate professionals and academicians given precedence to economic risks caused by these kind of financial factors [1], [4]. Moreover, marketing managerial factors such wrong estimated of demand and supply of the properties can cause an economic risk to real estate project [6], [7]. Other marketing risks related to this economic factor are such the

Manuscript received June 15, 2014; revised August 15, 2014. This work was supported in part by the Innovative Real Estate Development Programme, Faculty of Architecture and Planning, Thammasat University, Thailand.

Sukulpat Khumpaisal is with Innovative Real Estate Development Programme, Faculty of Architecture and Planning, Thammasat University, Pathumtani, 12121 Thailand (e-mail: Sukulpat@ap.tu.ac.th). characteristics, attribution of buyers and tenants. For example, investment in the commercial real estate assets delivers a return in form of an income stream, but the income stream is uncertain to forecast because of there are many unforeseen events or risks that affected to its' income stream [8]. It was suggested that some mandatory data should be added into economic risks criterion such as original and banks appraised value, capitalization rate from appraisal and loan to value at inception such as the economic risks could be measured by utilising a sensitivity analysis on the income/loss data of the property [4]. Amongst them, the interest rate was a significant indicator for measuring economic risks as the variation in interest rate affected the earnings by changing its net interest income, the level of other interest-sensitive income, and operating expenses associated with each specific real estate development, and those changes can also affect the underlying value of a firm's assets, liabilities and off-balance sheet instruments and the present value of future cash flows [9].

\section{AN OVERVIEW OF THAILAND REAL ESTATE BUSINESS CONTEXT}

The collapse of the global economic crisis in 1997 was caused by the downfall of Thailand's real estate development business [10]. The key reasons for this crisis were regard to financial institutions and real estate developers who lacked monetary discipline and neglected risks in real estate business. Moreover, Thai developers also did not have the practical risk assessment and management techniques to resolve the consequences of risks [11], [12].

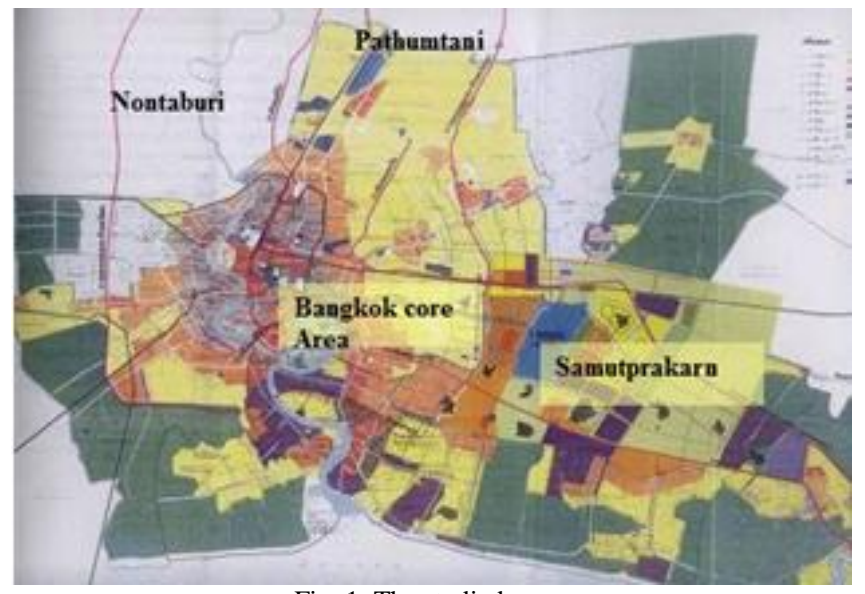

Fig. 1. The studied area.

Several Thai scholars [13]-[15] predict that the future trend of the Thai real estate sector will be similar to the circumstances in the 1997 crisis, as practical risk assessment techniques are yet to be developed. This prediction is 
supported by the incidents of the global recession from 2007 to 2010 , which significantly affected the Thailand property sector owing to the shortage of housing purchasing demand and less funding injected into the housing and residential sub-sector.

This article focuses on the real estate development projects in the Bangkok Metropolitan Area (BMA) and vicinity (see Fig. 1). This area is a heart of the Thai economic and political system, with the highest density of housing projects in comparison to the rest of Thailand [16]. [17]. It contains with the highest number of real estate developers - approximately 250 [18].

Despite the fact that Thai real estate developers experienced the waves of economic crises in 1997 and 2007-2010, but they are still less concerned with economic risks influenced to their project progress. As Thai developers lack of appropriate knowledge to assess, identify and understand the risks, and they are only interested in maximising the highest profit from their investment [14], [15]. Thai developers are still employing the non-systematic assessment methods such as intuition, or experience, which are not effective enough to assess the complexity of economic risks [19].

This article aims to put forward the proper risk assessment method to the Thailand's real estate industry, it also introduces the statistical devices that enable the decision makers to acknowledge the consequences of economic risks precisely. The research methodology and the established risk assessment criteria that used in the data collection phase are then discussed in the next section.

\section{RESEARCH METHODOLOGY}

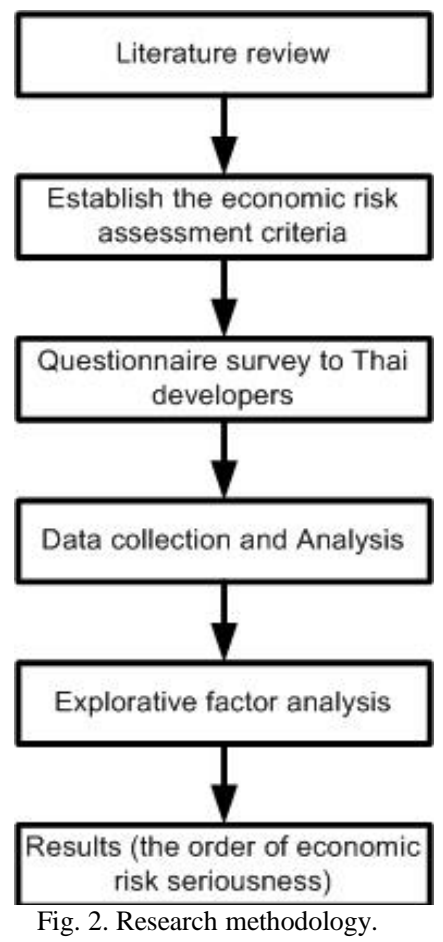

Methodologies adopted in this research consist of the extensive literature review and the quantitative survey. The questionnaires were distributed to Thai developers in the studied area (see Fig. 1), where each questionnaire set comprises 2 sections. The first section was designed to classify the respondents' profiles (experience, organisations, type of project, etc.), while the second section was aimed to gather the practitioners' perceptions towards economic risks. This section comprised 14 criteria, which had been separated into two pillars of "risk consequence" and "risk likelihood", respectively. Therefore, there are 28 variables contained in the economic risk criteria. Four hundred (400) sets of questionnaires were distributed to the sampled survey participants in January 2010 via post, email and hand-in methods. The response rate was $52.5 \%$ (210 of 400) which enabled the further statistical tests to be carried out. The data was analysed by descriptive statistical analysis, and the Explorative Factor Analysis (EFA), were used to analyse the attribution of respondents, then clustered the hierarchy of economic risks in Thailand real estate industry.

Overall research methodology is illustrated in Fig. 2.

\section{ECONOMIC RISK ASSESSMENT CRITERIA}

In order to level the perception of economic risk effectively, the economic risk assessment criteria were established, it contains with 14 risks, which related to marketing, macroeconomic and project funding aspects, they are briefly described as:

\section{A. Brand Awareness}

It is a media to convey the products to the target customers, it also builds the relationship between customers' perceptions towards products [20]. In the context of the property industry, the customers also perceived brand and reputation of developers and set it as one of the decision making criteria to buy houses [21]. This risk therefore measured by using the degree of developer's reputation in developing each specific real estate project [6], [22].

\section{B. Demand and Supply (Competitiveness)}

Thai developers confronted with the direct, and indirect competitors, and this risk shall be evaluated before the developed conducted the marketing strategy [23], then it is measured by using the degree of competitiveness of the same property type in the trade area [6].

\section{Demand and Supply (Wrong Estimation)}

This is related to the wrong-estimation of the real demand and the supplies of properties/ projects in the trade area. It affects the developers to decision whether invest or terminate their project [24]. Thus, this shall be measured by rating the degree of seriousness in wrong-estimating the demand and supply of similar property type [6].

\section{Market Liquidity (Selling Volume of Properties)}

It is an ability to undertake property transactions (gap between bidding and offer prices, speed in transaction etc.) in a way to adjust the projection rate and risk profiles without disturbing underlying prices. [25]. The selling volume of same kind of properties in the local trade area has been used to evaluate this risk.

\section{E. Market Liquidity (Selling Prices of Properties)}

Selling prices of product in the trade area is an indicator to measure the liquidity of market [21]. Therefore, the selling 
prices of properties in the local market were used to assess this market liquidity risk [6].

\section{F. Customer Affordability}

CurrentThailand economic/political situation influences the customers' confidence to buy houses, as well as an oversupply situation, and the prices of property dropped [16]. Therefore, this is evaluated by the mortgage rate, or housing loan rate issued by Thai commercial banks, in order to show the ability of customers to repay mortgage [21], [26].

\section{G. Effectiveness of Marketing Strategy}

The marketing strategy is a concept to build an organisation based on the profitable satisfaction of customers, and it helps achieving success in the competitive markets [27]. The number of property sold, produced and inventories are adopted as the indicator to measure the effectiveness of the developers' marketing strategy [21]. This is subjectively evaluated by scale or percentage of impact of project selling rate to the project marketing strategy [28].

\section{H. Development Fund}

This risk affects strongly to the real estate projects, in regardto the shortage of funds would delay the construction stage and lead to the loss of income stream [4], [6]. The amount of fund injected to the project and the sources of funding are considered as the indicators to measure this risk [29].

\section{Fluctuation of Interest Rate}

This affects to the project income stream, because of the variations in the interest rate or condition of payment are the crucial factors to the developers' cost of finance [1], [30]. This is assessed by degree of impacts to project investment in regard to an increment of interest rate [1], [30].

\section{J. Project Cash-Flow Liquidity}

As the developers have to build the properties against the pressure from the financial institutions, they also have to manage the construction cost, especially the contractors' payment, then it shall be measured by the degree of ability to pay the contractual sum [31].

\section{K. Investment Return}

The financial indicators such as IRR, NPV or ROI are normally used to measure the expected investment return in real estate such as [4], [31]. However, in order to assess the financial risk, the developers preferred the capitalisation rate as it helps in determining the rate of return quantitatively [30]. Hence, the percentage of capitalisation rate required by the project sponsors [1], [32] shall be used to evaluate risk caused by the expectation of investment return.

\section{Project Depreciation}

This is the loss in value of the building over time due to wear and tear, physical deterioration and age. However, this research only assess the perception of the developers towards property depreciation and its impact to the customers' decision making to buy property, this would be therefore measured by the property depreciation rate calculated by straight line method [33].

\section{The Variation of Construction Materials Prices}

This factor is typically influenced by the unstable economic situation and this leads to the project construction cost variation [34]. This paper used the reinforcement steel prices index issued by National Statistical Office Thailand [35], [36] as an indicator to measure this risk.

All economic risks criteria are summarized in Table I, which included criteria, evaluation methods, unit of measurement, and references.

\section{DEFINITION OF EXPLORATIVE FACTOR ANALYSIS}

Exploratory Factor Analysis is commonly used to identify the nature of the constructs underlying responses in a specific content area, determine the relationship of the sets of variables, and to demonstrate the dimensionality of a measurement scale including the most important factor when classifying a group of items. EFA provides "factor scores", which represent values of the underlying constructs for use in other analyses [38].

This EFA was conducted to determine the number of common factors influencing to a set of measures and the strength of the relationship between each economic risk. Besides that, this research employed the principal component analysis (PCA), because of this research is naturally an explorative research. The researcher did not have a causal model, but simply wants to reduce a large number of factors into a smaller number of underlying latent dimensions [39].

As earlier mentioned, there were 28 risks containing in an economic risk assessment criteria that included the consequences and frequencies of each factor. Then, EFA in this research was performed under the following basis steps [38], [40]:

- The correlation test was performed in order to generate a matrix of correlation coefficients to compare the possible pairings of the variables.

- Then all factors in the criteria were extracted by using the "principal components" extracting method.

- The factors (axes) were rotated to maximize the loadings of the variables as well as to reduce some trivia factors in order to achieve the simple structure. The "varimax" rotation method was used in this research, because it maintains independence amongst the mathematical factors, and also produces uncorrelated factors.

- Defining the factors by considering the possible theoretical constructed that could be responsible for the observed pattern of positive and negative loadings.

- Construct factor scores for further analysis, for the additional analyses using the factors as variables. The score for a given factor is a linear combination of all of the measures, weighted by the corresponding factor loading.

This EFA produced the rotated component matrices that used to describe the importance of each economic risk and to interpret the factors. It was considered that the factor loading indicated the importance of each economic risk, as well as the components after rotation represented the perceptions of risk's seriousness. The following rule of thumb to interpret the value of factor loading was employed as; the factor loadings should be 0.700 or higher to confirm that independent variables identified a priori that represented by a particular factor, $0.60-0.70$ as high, $0.51-0.59 \mathrm{~s}$ average and below, 0.40 as low [41], [42]. 
In this regard, the loadings less than 0.50 were then excluded from calculation in order to reduce some trivial factors, these variables were clustered into the group of "non significant factors" (see Table II). In addition, the Cronbach's alpha tests were used to test the reliability of the dimensions, where high correlation between items was found, this means it should be considered to validate and suggest a reliable dimension [43].

\section{RESULTS}

As earlier discussed, the real estate projects always affected by the economic risks, due to the characteristics of real estate project that is extensively income-generated projects, and economic risks are classified as the most complicated risks amongst the other source of risks [8], [44]. Thus, the economic risk assessment criteria had been modified to cover as much as possible economic risks in the real business case, it consisted of 28 variables, which grounded on risks caused by the marketing activities, financial risks, and business risks [44], [45].

These 28 variables had been merged together and then the reliability test was conducted. The Cronbach's alpha was indicated at 0.932 , so the research instrument (criteria and questionnaires) were reliable enough to conduct the factor analysis. The components analysis categorised group of economic risks into 8 factors, they were following named as:

The competitive situation. This was the largest component, it contained with 8 variables. The factor loadings of these variables were indicated between the lowest of 0.517 to the highest of 0.799 . This component reflected the perceptions of Thai practitioners towards the marketing competitors, in term of the competitors size, selling volume, and production prices. In this regard, the competitors also covered on the new competitors and substitute products (i.e. rental apartments). This finding was strengthen by Porter's five forces theory (1979), that the intensity of competitive rivalry is the major determinant of the competitiveness of any industries [23].

TABLE I: THE ECONOMIC RISK ASSESSMENT CRITERIA

\begin{tabular}{|c|c|c|c|c|}
\hline & Sub criteria & Evaluation methods (consequences and likelihood) & Unit of measurement & References \\
\hline A & Brand visibility & $\begin{array}{l}\text { Degree of developer's reputation in developing specific real } \\
\text { estate project }\end{array}$ & Scale or percentage & {$[22],[6],[37]$} \\
\hline $\mathrm{B}$ & Demand and supply & $\begin{array}{l}\text { Degree of competitiveness of the same property type in the } \\
\text { studied area; }\end{array}$ & Scale or percentage & [6] \\
\hline $\mathrm{C}$ & Demand and supply & $\begin{array}{l}\text { Degree of misestimate the demand and supply of similar property } \\
\text { type }\end{array}$ & Scale or percentage & {$[24],[6]$} \\
\hline $\mathrm{D}$ & Market liquidity & The selling volume of same kind of properties in the local market & $\begin{array}{l}\text { Number of properties selling in the trade } \\
\text { area }\end{array}$ & {$[21],[6]$} \\
\hline $\mathrm{E}$ & Market liquidity & The selling prices of same kind of properties in the local market; & Prices of similar kind of property (Baht) & [21], [6] \\
\hline $\mathrm{F}$ & $\begin{array}{l}\text { The customer } \\
\text { affordability }\end{array}$ & The ability of customer to pay back the mortgage. & $\begin{array}{l}\text { Mortgage rate, housing loan rate }(\% \text { per } \\
\text { annum) }\end{array}$ & {$[21],[16]$} \\
\hline G & Marketing strategy & $\begin{array}{l}\text { The impact of project selling volume and prices marketing } \\
\text { strategy }\end{array}$ & Scale or percentage & [28] \\
\hline $\mathrm{H}$ & $\begin{array}{l}\text { Sources and availability } \\
\text { of project fund }\end{array}$ & $\begin{array}{l}\text { The amount of fund injected to the project and the number of } \\
\text { funding sources availability to project investors }\end{array}$ & $\begin{array}{l}\text { The project value and debt/equity ratio, } \\
\text { or project sources of fund ratio }\end{array}$ & [29]. [4] \\
\hline I & Interest Rate & The variation of interest rate (loan) & $\begin{array}{l}\text { The current loan interest }(\%) \text { obtained } \\
\text { from bank }\end{array}$ & {$[1],[31]$} \\
\hline $\mathrm{J}$ & Cash-flow liquidity & The ability to pay the contractual sum to the subcontractors & The interim payment schedule & [32] \\
\hline $\mathrm{K}$ & Investment return & $\begin{array}{l}\text { Internal rate of return (IRR) and Capitalization rate required by } \\
\text { the project sponsors. }\end{array}$ & Percentage of rate of return & {$[33],[1]$} \\
\hline $\mathrm{L}$ & Project depreciation & The property depreciation rate (straight line method) & Percentage of depreciation per annum & {$[34]$} \\
\hline M & $\begin{array}{l}\text { The variation of } \\
\text { construction materials } \\
\text { price }\end{array}$ & The consumer price index (construction material mode) & The CPI indices (steel) & [36] \\
\hline
\end{tabular}

TABLE II: COMPETITIVE SITUATION FACTORS

\begin{tabular}{|c|c|c|c|c|c|c|}
\hline Risk Factor & Factor Loading & $\begin{array}{l}\text { Very low } \\
(\%)\end{array}$ & $\begin{array}{l}\text { Low } \\
(\%)\end{array}$ & Neutral (\%) & High (\%) & $\begin{array}{l}\text { Very High } \\
(\%)\end{array}$ \\
\hline \multicolumn{7}{|l|}{ Cronbach's Alpha $=0.932$} \\
\hline Frequency of the degree of competitiveness in the trade area. & 0.80 & 9.52 & 29.52 & 30.00 & 20.48 & 8.10 \\
\hline $\begin{array}{l}\text { Consequence of the degree of competitiveness in the } \\
\text { trade area. }\end{array}$ & 0.77 & 7.62 & 19.52 & 34.76 & 28.57 & 7.14 \\
\hline Consequence of the competitor's selling volume. & 0.74 & 5.24 & 23.33 & 39.05 & 25.24 & 3.81 \\
\hline Frequency of the competitor's selling volume. & 0.74 & 7.14 & 35.71 & 34.29 & 17.14 & 2.38 \\
\hline Frequency of the sell records of competitors. & 0.71 & 7.14 & 38.10 & 30.48 & 14.76 & 6.19 \\
\hline Consequence of the sell records of competitors. & 0.62 & 6.67 & 21.43 & 34.76 & 28.10 & 4.76 \\
\hline Frequency of the selling prices of competitors. & 0.61 & 7.62 & 39.05 & 30.00 & 16.19 & 2.38 \\
\hline Consequence of the selling prices of competitors. & 0.52 & 4.76 & 22.86 & 39.52 & 26.19 & 1.90 \\
\hline
\end{tabular}

Project income factors. 4 variables were counted in this component, all of them related to the influence of the project sources of income. The factor loading were in the rank between the lowest 0.616 to the highest 0.844 . The results revealed that Thai practitioners given much concern to the risks that caused by the illiquidity of project cash-flow and 
the less of income returned after invested in real estate projects. However, the risk that had the strongest influence to their project vitality was the risk caused by the financial institutions hesitation to issue the loan or did not endorse the developers' credit. It was because of the real estate project usually a big investment project that requires a large amount of invested money [46]. In the case of the financial institutions delaying their payment, that would affect strongly to the overall project monetary status, and the project progression, particularly during the construction stage [32] (Table III).
Project funding factors. This component consisted of 4 variables, it was quite similar to the project income factors, but this also included the risk caused by the obsolescence of property (property depreciation). The risk caused by the depreciation of property value would affect to marketing strategy in order to manage inventories, as well as to the potential of customers to buy a property and especially the speculators' point of view. It was because of the unsold properties would had less maintenances, then these reduced the value of properties in both physical and functional manner [34] (Table IV).

TABLE III: PROJECT INCOME FACTORS

\begin{tabular}{lllllll}
\hline \hline \multicolumn{1}{c}{ Risk Factor } & $\begin{array}{l}\text { Factor } \\
\text { Loading }\end{array}$ & $\begin{array}{l}\text { Very low } \\
(\%)\end{array}$ & $\begin{array}{l}\text { Low } \\
(\%)\end{array}$ & $\begin{array}{l}\text { Neutral } \\
(\%)\end{array}$ & High (\%) & $\begin{array}{l}\text { Very High } \\
(\%)\end{array}$ \\
\hline Consequence of illiquidity of project cash-flow. & 0.84 & 16.19 & 23.33 & 32.38 & 15.24 & 9.05 \\
Consequence of expectation of investment return. & 0.71 & 8.10 & 26.19 & 36.67 & 20.00 & 5.24 \\
Consequence of the amount and sources of funding. & 0.68 & 15.24 & 24.29 & 33.33 & 17.62 & 6.67 \\
Consequence of fluctuation of interest rate. & 0.62 & 11.90 & 22.86 & 37.62 & 21.90 & 1.43 \\
\hline \hline
\end{tabular}

TABLE IV: PROJECT FUNDING FACTORS

\begin{tabular}{lllllll}
\hline \hline \multicolumn{1}{c}{ Risk Factor } & $\begin{array}{l}\text { Factor } \\
\text { Loading }\end{array}$ & Very low (\%) & Low (\%) & Neutral (\%) & High (\%) & $\begin{array}{l}\text { Very High } \\
(\%)\end{array}$ \\
\hline $\begin{array}{l}\text { Frequency of the fluctuation of interest rate. } \\
\begin{array}{l}\text { Frequency of the amount and sources of } \\
\text { funding. }\end{array}\end{array}$ & 0.80 & 14.76 & 37.14 & 32.86 & 8.10 & 2.86 \\
$\begin{array}{l}\text { Frequency of the illiquidity of project } \\
\text { cash-flow. }\end{array}$ & 0.59 & 18.57 & 40.00 & 26.19 & 8.57 & 3.81 \\
Frequency of the property depreciation. & 0.55 & 13.33 & 36.19 & 27.14 & 8.10 & 4.29 \\
\hline \hline
\end{tabular}

TABLE V: MARKETING PLAN EFFECTIVENESS FACTORS

\begin{tabular}{|c|c|c|c|c|c|c|}
\hline Risk Factor & Factor Loading & $\begin{array}{l}\text { Very low } \\
(\%)\end{array}$ & Low $(\%)$ & Neutral (\%) & High (\%) & $\begin{array}{l}\text { Very High } \\
(\%)\end{array}$ \\
\hline $\begin{array}{l}\text { Frequency of the wrong estimation on demand and } \\
\text { supply of the properties. }\end{array}$ & 0.81 & 13.33 & 37.14 & 36.19 & 5.24 & 3.33 \\
\hline $\begin{array}{l}\text { Consequence of the wrong estimation on demand } \\
\text { and supply of the properties. }\end{array}$ & 0.59 & 11.43 & 27.62 & 39.52 & 11.43 & 4.76 \\
\hline Frequency of an ineffective marketing strategy. & 0.58 & 11.90 & 35.71 & 34.76 & 10.95 & 2.38 \\
\hline
\end{tabular}

TABLE VI: CONSTRUCTION MATERIALS FACTORS

\begin{tabular}{|c|c|c|c|c|c|c|}
\hline Risk Factor & $\begin{array}{l}\text { Factor } \\
\text { Loading }\end{array}$ & $\begin{array}{l}\text { Very low } \\
(\%)\end{array}$ & Low (\%) & $\begin{array}{l}\text { Neutral } \\
(\%)\end{array}$ & $\begin{array}{l}\text { High } \\
(\%)\end{array}$ & $\begin{array}{l}\text { Very High } \\
(\%)\end{array}$ \\
\hline The consequence of the fluctuation of construction materials prices. & 0.873 & 2.86 & 19.52 & 36.19 & 28.10 & 5.71 \\
\hline The frequency of the fluctuation of construction materials prices. & 0.816 & 4.76 & 36.19 & 33.81 & 13.33 & 5.71 \\
\hline
\end{tabular}

TABLE VII: CUSTOMER'S POTENTIAL FACTORS

\begin{tabular}{|c|c|c|c|c|c|c|}
\hline Risk Factor & Factor Loading & "Very low (\%) & Low $(\%)$ & Neutral (\%) & High $(\%)$ & "Very High (\%) \\
\hline Consequence of the customer's non-affordability. & 0.77 & 10.95 & 26.19 & 38.57 & 17.62 & 2.38 \\
\hline Frequency of the customer's non-affordability. & 0.62 & 12.86 & 40.48 & 31.43 & 9.52 & 1.43 \\
\hline
\end{tabular}

TABLE VIII: THE BRAND AWARENESS FACTORS

\begin{tabular}{llllll}
\hline \hline \multicolumn{1}{c}{ Risk Factor } & Factor Loading & Very low (\%) & Low (\%) & Neutral (\%) & High (\%) \\
\hline Frequency of the developer's brand awareness & 0.79 & 20.95 & 33.81 & 28.57 & 10.48 \\
Consequence of the developer's brand awareness & 0.66 & 18.57 & 23.33 & 30.48 & 20.95 \\
\hline \hline
\end{tabular}

TABLE IX: SUMMARY OF HIGH IMPACT RISKS

\begin{tabular}{|c|c|c|c|c|}
\hline No & $\begin{array}{l}\text { Categories } \\
\text { (Types) }\end{array}$ & Components (Factors) & Risk & $\begin{array}{l}\text { Factor } \\
\text { Loading }\end{array}$ \\
\hline 1 & Macroeconomic risks & $\begin{array}{l}\text { Construction material } \\
\text { prices }\end{array}$ & The consequence of the fluctuation of construction materials prices. & 0.87 \\
\hline 2 & Financial/monetary risks & Project income & The consequence of the illiquidity of project cash-flow. & 0.84 \\
\hline 3 & Marketing risks & $\begin{array}{l}\text { Marketing plan } \\
\text { effectiveness }\end{array}$ & $\begin{array}{l}\text { The frequency of the wrong estimation on demand and supply of the } \\
\text { properties. }\end{array}$ & 0.81 \\
\hline 4 & Financial/monetary risks & Project funding & The frequency of the fluctuation of interest rate. & 0.80 \\
\hline 5 & Marketing risks & Competitive situation & The frequency of the degree of competitiveness in the trade area & 0.79 \\
\hline
\end{tabular}


Marketing plan effectiveness factors. This factor extensively focused on the impact of the risks caused the inaccurate estimation of the demands for the properties of the potential customers, and the supply of similar kind of properties in the trade area. These mistakes also affected directly to the project marketing team in order to establish the updated marketing plan (Table V).

Construction materials. There were 2 variables contained in this component. Both of them specifically attended on the risks caused by the fluctuation of construction materials prices, particularly to the increment of reinforcement steel (re-bar), due to these re-bar are necessary to every construction projects, but there were some limitation in manufacturing of these steels (raw materials, delivery lead time). These risks therefore influenced to the developers' pricing strategy of the properties, in regard to increase the ended products' prices but diminished the customers' affordability. These findings supported that the fluctuation of construction materials prices had intensely influenced to the developers' perceptions of economic risks [19] (Table VI).

Customers' potential factors. Thai practitioners considered that risks caused by the lack of affordability of the project's customers had the higher impact to the flow-ability of project income and funding. In addition, this risk also cover on the risk initiated by the financial institutions and the ability to pay back housing-loan of the mortgagors. As the nature of Thai real estate customers, they had to mortgage their property with the financial institutions in order to purchase properties. Thus, if there were any changes in the condition of loan payments such as increment of interest rate, or the instalment terms, these activities would affect directly to the customers' affordability and reacted to the developers' income consequently [15] (Table VII).

The brand awareness factors. The risks caused by the customers in the trade area did not recognise in the developers' brand were considered as one of the serious issue by the Thai practitioners, it was straightforwardly affected to the establishments of developers' marketing plan/strategy. In Thailand real estate business case, the small or medium developers always find some difficulty to build their own brand loyalty as well as hard to sell their properties as planned and within the limited budget [47].

Non significant factors. This component contained with 3 variables, which were the consequence of the property depreciation affect to project, the frequency of the expectation of investment return affect to project, and the consequence of the marketing strategy' effectiveness affect to projects. These had been considered by Thai practitioner as they did not influence strongly to the project progress and vitality. In this case, the factor loadings of these 3 variables did not exceed 0.50 , thus these criteria had been eliminated from the component analysis [37] (Table VIII).

The findings of the EFA insisted that Thai real estate practitioners mostly concerned on the consequences and the likelihood of economic risks. It is because of the economic risks (in any form) critically influence the decision-making processes towards project management strategy/plans. The results also revealed that they perceived the crucial competitive situation in Thailand real estate business sector, as the practitioners justified that risks caused by the competitors became the first priority risk that needed to be concerned. Moreover, the analysis informed that Thai practitioners also concern on the matter of project cash-flow illiquidity and its affect to the project income stream as the factor loading derived at 0.844 , which was the highest figure amongst the rest variables.

The fluctuation of construction materials' price became the second priority risk that affected to this industry. The factor loading's value indicated at 0.873 (the consequences) and 0.816 (frequency) this risk was particular uncontrollable, since it is related with other external factors such as the variation of currency exchange rate [19] or the unstable economic situation [36]. This factor lead to the variation of construction cost

Marketing risks was an another economic risk that need to be emphasised while managing real estate projects, the results revealed that Thai practitioners paid attentions to these risks, particularly the misinterpretation of properties supply and demand in the trade area, its loading was 0.809 . This risk reflected to the capability of the marketing team in term of the team may have a wrong estimation of demand and supply of the similar properties type in the trade area or the marketing teams have inadequate information of the customers' behaviours and affordability [47].

Moreover, the survey results underpinned that economic risks can be classified into 3 major categories as macroeconomic risks, financial/monetary risks, and marketing risks respectively. The macroeconomic risks are represented by the seriousness of the fluctuation of construction materials prices. The consequence of the illiquidity of project cash-flow preparation and the frequency of interest rate's fluctuation signify the seriousness of financial/monetary risks, whereas the marketing risks are mostly caused by the wrong estimation of supply/demand area as well as by the competitive situation in the trade area. Therefore, it is construed that Thai practitioners emphasised on the impact of financial/monetary risks amongst the others, following by the macroeconomic and marketing risks. The summary of the high impact economic risks in Thailand's real estate industry are shown in Table IX.

\section{CONCLUSION}

The Explorative Factor Analysis (EFA) is implemented in this article in order to assess the impact of the Thai real estate practitioners' towards economic risks. The samplers of this study were Thai developers, who developed the project in Bangkok Metropolitan Area (BMA), and the number of respondents was 210, those were adequate to perform this EFA effectively. The literature review informed that the systematic risk assessment method was too far remote from this industry, but Thai developers still need the proper method in order to deal with the complicatedness of economic risks.

According to the EFA analysis' factor loadings as shown in Table II and III, it informs that Thai practitioners given the to the risks caused by the variation of construction materials' price, as this is a complicated risk related to the uncontrollable factors such as the instable economic and political situation or the variation of currency rate. The results also notify that Thai practitioners concern on the 
consequence and likelihood of economic risks to their projects. While the component analysis performed in this EFA help the researchers classifying the economic risks (in the assessment criteria) into the appropriate categories. It also helps in adjusting the seriousness of economic risks and informing the practitioner about the priority of each risk.

However, the risk assessment criteria used in the research was developed based on the European perceptions towards economic risks, further research along with a huge amount of information from Thai practitioners, from a variety of real estate projects, are indeed required, in order to modify and improve the risk assessment criteria to suit the Thailand's property industry context.

\section{REFERENCES}

[1] J. M. Griffin, X. Ji, and J. S. Martin, "Momentum investing and business cycle risk: Evidence from pole to pole," The Journal of Finance, vol. 58, no. 6, pp. 2515-2547, 2003.

[2] R. J. Shiller, "Derivatives markets for home prices (No. w13962)," National Bureau of Economic Research, 2008.

[3] R. Nabarro and T. Key. (April 2005). Performance measurement and mega-project lending risk. Real Estate Indicators and Financial Stability. [Online]. $\quad$ pp. 70-90. Available: http://www.bis.org/publ/bppdf/bispap21.htm

[4] D. Strischek, "Regulatory guidance on commercial real estate risk: mind the gap for great guidance on good lending," The RMA Journal, April 2007.

[5] J. N. Smith, T. Merna, and P. Jobling, Managing Risk in Construction Projects, $2^{\text {nd }}$ ed. Blackwell Publishing, 2006.

[6] A. Adair and N. Hutchison, "The reporting of risk in real estate appraisal property risk scoring," Journal of Property Investment and Finance, vol. 23, no. 3, pp. 254-268, 2005.

[7] R. Miller and R. D. Lessard, Evolving Strategy: Risk Management and The Shaping of Mega-Project, Decision-Making on Mega-Projects. Cost-Benefit Analysis, Planning and Innovation, Edward Elgar Publishing, Massachusetts, USA, 2008.

[8] P. Booth, G. Matysiak, and P. Ormerod, "Risk measurement and management for real estate portfolios," Report for the Investment Property Forum (IPF), London, 2002.

[9] FSA. (2005). Strengthening capital standards. Financial Services Authority (FSA), London. [Online]. Available: http://www.fsa.gov.uk/pubs/cp/cp05_03.pdf

[10] G. P. Warr, "What happened to Thailand?" The World Economy, London: Blackwell Publishing, vol. 22, issue 5, pp. 631-650, 2000.

[11] M. J. Quigley, "Real estate and the Asian crisis," Journal of Housing Economics, vol. 10, pp. 129-161, 2001.

[12] S. L. Lauridsen, "The financial crisis in Thailand: causes, conduct and consequences?” Journal of World Development, vol. 26, no. 8, pp. 1575-1591, 1998.

[13] S. Vanichvatana, "Thailand real estate market cycles: case study of 1997 economic crisis," Government Housing Bank Journal, vol. 1, no. 1, pp. 38-47, 2007.

[14] S. Pornchokchai, "Rethinking the real estate cycle," Government Housing Bank Journal, vol. 1, no. 1, pp. 48-59, 2007.

[15] B. Kritayanavaj, "Housing bubble," Government Housing Bank Journal, vol. 1, no. 1, pp. 70-76, 2007.

[16] REIC. Summary of Thailand Real Estate Condition. Real Estate Information Centre, Thailand. [Online]. Available: http://www.reic.or.th/SummaryRealEstate/SummaryRealEstate_index .asp

[17] Office of the National Economic and Social Development Board: NESDB. Thailand in Brief: 2006. Office of the National Economic and Social Development Board, Bangkok, Thailand. [Online]. Available: http://www.nesdb.go.th/Default.aspx?tabid=136

[18] APTU, Residential Project Feasibility Study; New Bangkok International Airport Area, National Housing Authority (Thailand), Faculty of Architectural and Planning Thammasat University, Thailand, 2006.

[19] S. Khumpaisal, S. A. Ross, and R. Abdulai, “An examination of Thai practitioners' perceptions of risk assessment techniques in real estate development projects," Journal of Retail and Leisure Property, vol. 9, no. 2, pp. 151-174, 2010.

[20] K. E. Macdonald and M. B. Sharp, "Brand awareness effects on consumer decision making for a common, repeat purchase product: A replication," Journal of Business Research, vol. 48, pp. 5-15, 2000.
[21] AREA, Housing Yellow Page, Veeruch Printing Co., Ltd, Bangkok, 2008.

[22] Dun \& Bradstreet Inc. (2007). Risk management. Dun \& Bradstreet Inc. London, UK. [Online]. Available: http://www.dnb.co.uk/Risk_Management/Risk_Management.asp

[23] M. E. Porter. (2008). The Five Competitive Forces That Shape Strategy. Harvard Business Review. [Online]. Available: http://www.hbr.org.

[24] Your Advice \& Education on Realty Development (YAERD). (2010). Determining Supply and Demand in Real Estate, the organizational. [Online]. Available: http://www.yaerd.org/articles/Determining-Supply-and-Demand-in-RealEstate.html

[25] A. Crockett, "Market liquidity and financial stability," Banque de France, Financial Stability Review - Special Issue on Liquidity, no. 11, 2008.

[26] House of Common, Affordability and the Supply of Housing, House of Commons ODPM: Housing, Planning, Local Government and the Regions Committee, The Stationery Office by Order of the House published, Third Report of Session 2005-06, 2006.

[27] QuickMBA.com. (2010). Market segmentation. Quick MBA Strategic management. [Online]. Available: http://www.quickmba.com/marketing/market-segmentation/

[28] G. R. Massey and P. L. Dawes, "Personal characteristics, trust, conflict, and effectiveness in marketing/sales working relationships," European Journal of Marketing, vol. 41, no. 9/10, pp. 1117-1145, 2007.

[29] A. Adair, J. Berry, S. McGreal, B. Deddis, and S. Hirst, "The financing of urban regeneration," Land Use Policy, vol. 17, pp. 147-156, 2000.

[30] K. E. Case, R. J. Shiller, and A. N. Weiss, "Mortgage default risk and real estate prices: the use of index-based futures and options in real estate," Journal of Housing Research, vol. 7, no. 2, pp. 243-258, 1995.

[31] K. C. Lam, H. Tiesong, S. O. Cheung, R. K. K. Yuen, and Z. M. Deng, "Multi-project cash flow optimization: non-inferior solution through neuro-multiobjective algorithm," Engineering, Construction and Architectural Manage, vol. 8 , pp. 130-144, 2001.

[32] C. J. Watkins, S. C. Hughes, R. Sims, M. E. Hildebran, and B. D. Hoyer, Assessing Commercial Real Estate Portfolio Risk, Supervisory Insights, Federal Deposit Insurance Corporation, Washington, USA, 2004 .

[33] A. Andrew and M. Pitt, "Property depreciation in government," Journal of Property Investment \& Finance, vol. 24, no. 3, pp. 259-263, 2006.

[34] V. T. Luu, S.-Y. Kim, N. V. Tuan, and S. O. Ogunlana, "Quantifying schedule risk in construction projects using Bayesian belief networks," International Journal of Project Management, vol. 27, no. 1, pp. 39-50, 2009.

[35] National Statistical Office Thailand (NSO). (2010). Consumer Prices Index. [Online]. Available: http://www.web.nso.go.th/eng/std/std.htm

[36] V. A. Gibson and M. Louragand, "Risk management and the corporate real estate portfolio," Working Paper, Centre for Real Estate Research, Business School, The University of Reading, UK, 2002.

[37] L. R. Fabrigar and D. T. Wegener, Exploratory Factor Analysis, Oxford University Press, 2011.

[38] G. D. Garson. (2010). Factor Analysis, North Carolina State University. [Online]. http://www.faculty.chass.ncsu.edu/garson/PA765/factor.htm

[39] R. P. Kinnear and D. C. Gray, SPSS 15 Made Simple, East Sussex, Psychology Press, UK, 2008.

[40] J. E. Raubenheimer, "An item selection procedure to maximize scale reliability and validity," South African Journal of Industrial Psychology, vol. 30, no. 4, pp. 59-64, 2004

[41] J. F. Hair, R. L. Tatham, R. E. Anderson, and W. Black, Multivariate Data Analysis, $6^{\text {th }}$ ed. Upper Saddle River, NJ: Pearson Prentice Hall, 2006.

[42] A. D. Ross, "A model of contingency factors affecting contractors' economic organization of projects," PhD. Thesis, School of Construction and Property, University of Salford, Salford, UK, 2005.

[43] F. E. Huffman, "Corporate real estate risk management and assessment," Journal of Corporate Real Estate, vol. 5, no. 1, pp. 31-41, 2002 .

[44] S. Khumpaisal, A. D. Ross, and R. T. Abdulai, "An examination of Thai practitioners' perceptions of risk assessment techniques in real estate development projects," Journal of Retail \& Leisure Property, vol. 9, no. 2, pp. 151-174, 2010 .

[45] D. J. Benjamin, G. S. Sirmans, and N. E. Zietz, "Returns and risk on real estate and other investments: More evidence," Journal of Real Estate Portfolio Management, vol. 7, no. 3, 2001.

[46] S. Sen, "The effects of brand name suggestiveness and decision goal on the development of brand knowledge," Journal of Consumer Psychology, vol. 8, no. 4, pp. 431-455, 1999. 
[47] R. N. Stone and K. Gronhaug, "Perceived risks: further considerations for the marketing discipline," European Journal of Marketing, vol. 27, no. 3, pp. 39-50, 1993.

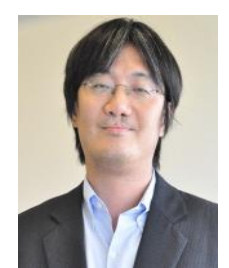

Sukulpat Khumpaisal is currently an instructor at the Innovative Real Estaet Development Programme, Faculty of Architecture and Planning, Thammasat University, Thailand. He was born in Bangkok in 1975. He completed the $\mathrm{PhD}$ degree in real estate development from Liverpool John Moores University, UK in 2011 , and master degree of project management from Univesity of South Australia in 2000, and bachelor degree of art (social science) from Kasetsart University in 1995.
He had more than 12 years working experience in both of private and international firms, which included working as a planning engineer, cos estimator, building managers, and property appraisers. With the title of the aforementioned publications included this article, it indicated that Sukulpat Khumpaisal's research interests was emphasizing on risk assessment particularly risks in the real estate development and construction schemes.

Dr. Sukulpat Khumpaisal is currently a member of Thailand Facility Management (TFMA). He hopes that this article would help Thai real estate developers to acknowledge the seriousness of risks in their business and seek for an appropriate tool to assess risks. 